PN II8I

\title{
Biosynthesis of odd- and even-numbered cerebroside fatty acids: Evidence for two routes
}

Biosynthesis of the longer saturated fatty acids can be considered to involve two steps: (I) synthesis of a primary fatty acid, usually palmitate, and (2) chain lengthening of the primary acid by addition of acetate moieties. The odd-numbered acids appear to be made by the same enzyme systems, starting with propionate instead of acetate at the $\omega$-end. We present here evidence that a similar pair of steps is involved in the formation of the very long acids, lignoceric $\left(24: 0^{\star}\right)$, cerebronic $(24 \mathrm{h:0}$ ), and their close homologs. Evidence is presented also which indicates that the $23 \mathrm{~h}: 0$ acid, and possibly other hydroxy acids, are made by a second route, a I-carbon degradation of a longer acid.

Weanling rats were given a single injection of $\left[\mathrm{I}^{-14} \mathrm{C}\right]$ acetate and groups were killed at various intervals. Cerebroside and whole brain acids were isolated from the pooled brains and the activities of most of the saturated acids were determined ${ }^{1}$. In the case of the hydroxy acids, degradation was carried out with $\mathrm{KMnO}_{4}$-acetic acid. The $\mathrm{CO}_{2}$, from the $\mathrm{COOH}$ group, was collected in hyamine and the resultant shorter acid was recovered by extraction. A similar degradation was carried out on the normal (non-hydroxy) acids with $\mathrm{NaN}_{3}-\mathrm{H}_{2} \mathrm{SO}_{4}$. Both the $\mathrm{CO}_{2}$ and the resultant fatty amine were counted. Recoveries of ${ }^{14} \mathrm{C}$ in both types of degradation were usually over $95 \%$ and over-degradation amounted to only a few percent.

TABLE I

ACTIVITY IN THE COOH GROUP AS PERCENT OF ACTIVITY IN. TOTAL ACID

\begin{tabular}{|c|c|c|c|c|c|c|c|c|}
\hline \multirow{2}{*}{$\begin{array}{c}\text { Interval } \\
\text { after injection }\end{array}$} & \multicolumn{8}{|c|}{ Fatty acid } \\
\hline & $16: 0^{*}$ & 18:0 & $18: 0^{\star}$ & $22: 0$ & 23:0 & 24:0 & $23 h: 0$ & $24 h: 0$ \\
\hline $4 h$ & 12.9 & 18.2 & 20.7 & 34.8 & & I5.7 & & I7.9 \\
\hline to $\mathrm{h}$ & 12.7 & 10.9 & I 8.2 & - & $26.9^{\star \star}$ & I5.6 & $18.9^{\star \star}$ & I 5.6 \\
\hline 4 days & 12.3 & II. 2 & I 1.7 & - & & I3.I & & 12.3 \\
\hline 14 days & - & - & - & - & - & - & - & II.4 \\
\hline 28 days & $x 2.2$ & I0.9 & 8.0 & 一 & 3 I. 7 & 8.I & $4 \cdot 3$ & 8.8 \\
\hline 56 days & 12.9 & 10.2 & 6.0 & - & 22.2 & 7.8 & 2.9 & 8.3 \\
\hline $\begin{array}{l}\% \text { calculated } \\
\text { for "total- } \\
\text { acetate" }\end{array}$ & & & & & & & & \\
\hline synthesis & I2.5 & I I.I & II.I & $9 \cdot I$ & 10.0 & $8 \cdot 3$ & 10.0 & 8.3 \\
\hline
\end{tabular}

* Acids from whole brain. Other acids from brain cerebrosides.

* Derived from samples pooled from first three groups of rats.

Table I shows the activity found in the $\mathrm{COOH}$ carbon atom, calculated as percent of the activity in the whole acid. The $16: 0$ acid shows a striking uniformity in the distribution of ${ }^{14} \mathrm{C}$, corresponding to that expected if it were the primary acid, derived from "total-acetate" synthesis. The ratio is maintained over a long period of time, through a wide range of activities (a high of 98530 counts/min per brain at $4 \mathrm{~h}$ to

* The abbreviations for the fatty acids show the number of carbon atoms and the number of double bonds. The $h$ indicates an $\alpha-O H$ group is present. 
a low of $3^{1} 5^{0}$ counts/min at $5^{6}$ days). The data for $18: 0$ acid of cerebrosides can be interpreted similarly, if one disregards the first time point. It may be ${ }^{2}$ that the cerebroside acids, unlike the other acids, are synthesized in just one type of brain cell, and that this cell makes $18: 0$ acid as its primary fatty acid.

In contrast, the $\mathrm{COOH}$ groups of all the other acids (with the possible exception of $23: 0$ ) have activities which are high at the beginning and decrease with time. This is the finding to be expected if chain lengthening of a basic acid is the biosynthetic mechanism. In the case of whole brain I 8:0 acid, for example, the molecules made during the earliest time period are presumably formed from non-radioactive I6:0 acid and highly radioactive acetate. This explains the 4 -h values, which are well above the percentages to be expected from uniform, "total-acetate" synthesis. As time goes on, the radioactive acetate available in the brain becomes much diluted and the later I 8:0 molecules are made from relatively highly radioactive I6:0 acid and only slightly radioactive acetate. These molecules will have very little radioactivity in the $\mathrm{COOH}$ group. The mixture of old and new molecules will exhibit an intermediate value for the $\mathrm{COOH}$ activity, the exact value depending primarily on the relative turnover rates of the three compounds involved.

This explanation is consistent with the finding that the $18: 0$ acid of whole brain loses its $\mathrm{COOH}$ percentage activity relatively rapidly, reaching only $6 \%$ by 56 days. The total-activity data for this acid show it has a much higher turnover rate than the cerebroside acids, going from a high of $36 x 80$ counts/min per brain at 4 days to a low of 8900 counts/min at 56 days. The long cerebroside acids (except $23 \mathrm{~h}: 0$ ) show slower losses of activity and slower declines in $\mathrm{COOH}$ percentage activity.

Examining the data in Table I for the $23: 0$ and $23 \mathrm{~h}: 0$ acids, we see again a very high relative activity in the $\mathrm{COOH}$ group shortly after injection. This is consistent with our finding ${ }^{1}$ that ${ }^{\left[{ }^{14} \mathrm{C}\right]}$ propionate is a precursor of the odd-numbered cerebroside acids, and supports the hypothesis that a primary odd-numbered acid (I7:0?) is lengthened by acetate addition. However, the hydroxy acid shows a remarkably fast drop in $\mathrm{COOH}$ percentage activity despite the fact that its total activity rises steadily with time. This drop could be the result of some synthesis of 23 h:0 from 24:0 or $24 \mathrm{~h}: \mathrm{o}$ acid by a I-carbon ( $\alpha$-oxidation) degradation process. Such a process has been found in plants ${ }^{3}$ and has been suggested for the odd-numbered cerebroside acids by FulCO AND MEAD ${ }^{4}$.

As a further test of the $\alpha$-degradation hypothesis, we degraded some of the hydroxy acid samples further and obtained the following percentages of total activity:

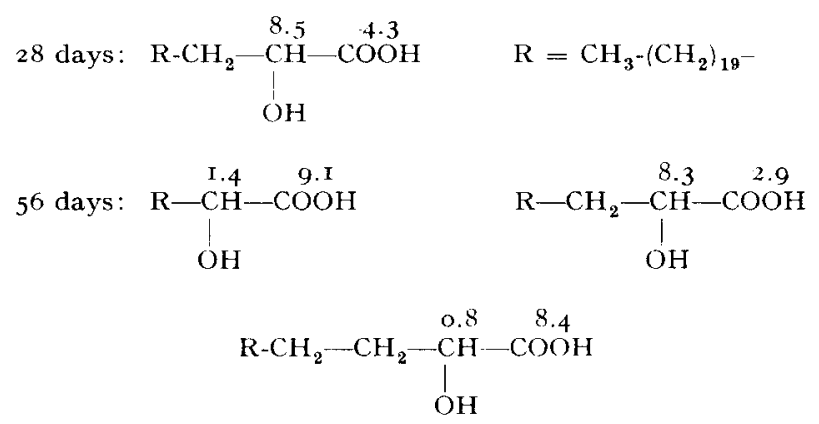

Biochim. Biophys. Acta, 70 (1963) 97-99 
The high activity in the $\alpha$-carbon of the two samples of $23 \mathrm{~h}: 0$ acid, in contrast to the distribution in the $22 \mathrm{~h}: 0$ and $24 \mathrm{~h}: 0$ acids, supports the hypothesis. Apparently the molecules of $23 \mathrm{~h}: 0$ formed shortly after injection are made from non-radioactive primary acid (17:0?) and $24 \mathrm{~h}: 0$ acid and highly radioactive acetate. The later molecules are formed from slightly active acetate, somewhat active primary acid, and $24 \mathrm{~h}: 0$ acid whose $\alpha$-carbons are only slightly labeled. The data do not rule out direct conversion of $24: 0$ to $23 \mathrm{~h}: 0$, or $\alpha$-degradation of the odd-numbered acids to form even-numbered acids. The data for the normal acid, 23:0, indicate that synthesis from propionate is the only important route.

Dr. MEAD has kindly told us of a similar degradation study with younger rats which supports the $\alpha$-degradation scheme for $23 \mathrm{~h}: 0$ synthesis.

Mental Health Research Institute, University of Michigan, Ann Arbor, Mich. (U.S.A.)

AMIYa K. HaJRA

NORMAN S. RADIN

1 A. K. HajRa and N. S. Radin, J. Lipid Res., 3 (1962) 327.

${ }^{2}$ N. S. Radin ANd Y. AKahori, J. Lipid Res., 2 (I96I) 335.

3 R. O. Martin and P. K. StumpF, J. Biol. Chem., 234 (I959) 2548.

${ }^{4}$ A. J. Fulco and J. F. Mead, J. Biol. Chem., 236 (I96I) 2416.

Received September I7th, I962

Biochim. Biophys. Acta, 7o (1963) 97-99

PN II82

\section{Sur la présence d'ornithine dans des lipides bactériens*}

Le principal constituant azoté présent dans la fraction phosphatidique des Mycobactéries a été identifié à la L-ornithine par GENDRE ET LEDERER ${ }^{1}$; ce résultat a été confirmé par la suite ${ }^{2}$. De petites quantités d'autres acides aminés peuvent exister à côté de l'ornithine ${ }^{2,3}$.

L'ornithine a été retrouvée, à côté d'éthanolamine, dans les produits d'hydrolyse de phospholipides de Vibrio cholerae $e^{4}$ et de Brucella melitensis ${ }^{5}$, et à côté d'autres acides aminés, dans ceux de Salmonella typhosa $a^{6}$.

Tous ces travaux ont montré la présence d'ornithine, sans apporter de précision sur la forme sous laquelle elle existe dans les phospholipides considérés. Cependant, dans une note récente, PAUL ET VILKas ${ }^{7}$ ont décrit l'isolement, à partir des produits de saponification des phospholipides de Mycobacterium phlei, d'une petite quantité ( $3 \%$ du phospholipide de départ) d'une fraction insoluble dans l'eau et soluble dans le chloroforme, contenant tous les acides aminés présents dans le produit initial; aucune recherche de phosphore sur cette fraction n'est mentionnée.

Nous étudions actuellement les lipides d'une souche de Mycobactérie, No. I2I7, reçue de Varsovie par l'intermédiaire du Professeur Hauduroy (Lausanne), qui

״ 2 ème communication sur la chimie des micro-organismes; rère comm., voir réf. I I. 